Review Article

\title{
Regulatory Requirement and Steps for Registration and Approval of Indian Drug Products in Overseas Market
}

\author{
Rushikesh Aher*, Pratik Aher, Tejas Ahire, Hitesh V. Shahare, Charulata T. Nemade \\ SNJB'S Shriman Sureshdada Jain College of Pharmacy, Chandwad, Maharashtra, India. \\ *Corresponding author's E-mail: aher.rushi77@gmail.com
}

Received: 21-04-2021; Revised: 28-05-2021; Accepted: 06-06-2021; Published on: 15-06-2021. \begin{abstract}
The Indian pharmaceuticals market is the third largest in terms of volume and thirteenth largest in terms of value. It has established itself as a global manufacturing and research hub. A large raw material base and the availability of a skilled workforce give the industry a definite competitive advantage. India has one of the lowest manufacturing costs in the world. The regulatory requirements of various countries of the world vary from each other. Therefore, it is challenging for Indian companies to develop a single drug that can be simultaneously submitted in all the countries for approval. The role of the regulatory authorities is to ensure the quality, safety, and efficacy of all medicines in circulation in their country. It not only includes the process of regulating and monitoring the drugs but also the process of manufacturing, distribution, and promotion of it. One of the primary challenges for regulatory authority is to ensure that the pharmaceutical products are developed as per the regulatory requirement of that country. This process involves the assessment of critical parameters during product development. This article covers the processes involved and requirements like import-export code, technical documentation, filing and reviewing process of drug master file, certificate of pharmaceutical product, common technical document (CTD), eCTD, and ACTD, for the registration and approval of Indian drug products in the overseas market
\end{abstract}

Keywords: Import Export Code, DMF, CTD, eCTD, ACTD.

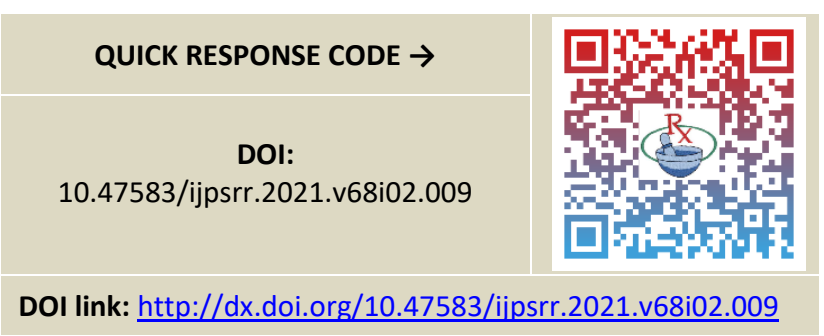

\section{INTRODUCTION}

T he Indian pharmaceutical industry is considered one of the fastest-growing sectors in the country and has exhibited considerable growth in recent years. It is one of the high-performing knowledge-based segments of the manufacturing sector. In addition to catering to the needs of the domestic demand, the pharmaceutical industry is also engaged in contract manufacturing, contract research, clinical trials, contract R\&D, and direct exports to developing and developing country markets. The industry has an eminent position in the global pharmaceutical market and is one of the leading producers of generic pharmaceutical products in the world, catering to approximately one-fifth of the global generic Pharma market. ${ }^{1}$ The Indian Pharma Industry exports its products to more than 200 countries in the world, including strictly regulated markets such as the US, Europe, and Japan. Regulatory supervision and quality monitoring of medicines and other pharmaceutical products are of vital importance. In this context, this study examines the regulatory landscape in highly regulated markets of the US, the EU as well as that of India and then analyses the trend in the world and India's international trade in pharmaceutical products and suggests select measures which could help the Indian industry move higher up the export growth trajectory. Due to the emerging regulatory needs of the pharmaceutical sector, the drug evaluation for the control of drug quality and trade has become highly sophisticated. Regulatory guidelines and standard tools provide a basis for the implementation of laws, whereas laws provide a legal basis for drug control. The world covers more than 100 countries, where most of them have established pharmaceutical legislations and regulatory requirements. For worldwide regulatory dossier submissions, it is a pre-requisite requirement to know country-specific guidelines and norms. Therefore, it is very important to analyse the differences and commonness between the regulatory requirements and pharmaceutical legislations of different countries of the world. ${ }^{2}$ The Pharmaceutical market is based on the diversity in the regulation region. Regulatory authorities of various countries are enlisted as follows:

Table 1: Illustrates the regulatory authorities of various countries $^{2,3}$

\begin{tabular}{|c|c|}
\hline Name of Country & Regulatory authority \\
\hline USA & USFDA \\
\hline European Union (EU) & EMA \\
\hline Canada & HPFB \\
\hline Japan & PMDA \\
\hline Australia & TGA \\
\hline South Africa & MCC \\
\hline LATAM (Brazil) & $\begin{array}{c}\text { Independent regulatory } \\
\text { agencies/ANVISA }\end{array}$ \\
\hline
\end{tabular}




\begin{tabular}{|c|c|}
\hline CIS (Russia) & $\begin{array}{c}\text { Independent regulatory } \\
\text { agencies/ROSZDRAVANADZOR }\end{array}$ \\
\hline AFRICA (Tanzania) & $\begin{array}{c}\text { Independent regulatory } \\
\text { agencies/TFDA }\end{array}$ \\
\hline ASIAN (Hong Kong) & $\begin{array}{c}\text { Independent regulatory } \\
\text { agencies/DOH }\end{array}$ \\
Independent regulatory \\
GCC
\end{tabular}$\quad$\begin{tabular}{c} 
agencies/ National filling \\
\hline
\end{tabular}

\section{Pharmaceutical Industry in India}

The Indian pharmaceuticals market is the third largest in terms of volume and the thirteenth largest in terms of value. It has established itself as a global manufacturing and research hub. A large raw material base and the availability of a skilled workforce give the industry a definite competitive advantage. India has one of the lowest manufacturing costs in the world. It is lower than that of the USA and almost half of Europe. The Indian pharmaceutical industry is expected to grow at a compound annual growth rate (CAGR) of 22.4 percent to touch US\$ 55 billion by $2020 .^{4}$

\section{Export Highlights ${ }^{5}$}

- $\quad$ Pharmaceutical export from India stood at US\$19.13 billion in 2018-19 and reached US\$ 9.36 billion in 2019-20 (till October 2019).

- It is expected to grow by 30 percent to reach US\$20 billion by the year 2020 .

- In 2018-19, top importers of India's pharmaceutical* products were the USA (US\$ 119.18 million), Russia (US\$ 10.33 million), UK (US\$ 9.83 million), South Africa (US\$ 3.63 million), and Nigeria (US\$ 1.71 million).

- India is expected to rank amongst the top three pharmaceutical markets in terms of incremental growth by 2020 .

- India is the largest supplier of generic medicines globally (20 to 22 percent of global export volume)

\section{Procedure for Export of Pharmaceutical Products}

India's Foreign Trade i.e., Exports and Imports are regulated by Foreign Trade Policy notified by Central Government in the exercise of powers conferred by section 5 of foreign trade (Development and Regulation) Act 1992. Presently Foreign Trade Policy 2015-20 is effective from $1^{\text {st }}$ April 2015. As per FTD \& R act, export is defined as an act of taking out of India any goods by land, sea, or air and with a proper transaction of money.

\section{Steps involved in Export ${ }^{6,7}$}

Export in itself is a very wide concept and a lot of preparations are required by an exporter before starting an export business. To start an export business, the following steps may be followed:

\section{Establishing an Organization}

To start the export business, first, a Sole Proprietary concern/ Partnership firm/Company has to be set up as per procedure with an attractive name and logo.

\section{Opening a Bank Account}

A current account with a bank authorized to deal in Foreign Exchange should be opened.

\section{Obtaining Permanent Account Number (PAN)}

Every exporter and importer must obtain a PAN from the Income Tax Department.

\section{Obtaining Importer-Exporter Code (IEC) Number}

- As per the Foreign Trade Policy, it is mandatory to obtain IEC for export/import from India. Para 2.05 of the FTP, 2015-20 lays down the procedure to be followed for obtaining an IEC, which is PAN-based.

- An application for IEC is filed online at www.dgft.gov.in as per ANF 2A, online payment of application fee of Rs. 500/- through net Banking or credit/debit card is made along with requisite documents as mentioned in the application form.

\section{Registration cum membership certificate (RCMC)}

For availing authorization to import/ export or any other benefit or concession under FTP 2015-20, as also to avail the services/ guidance, exporters are required to obtain RCMC granted by the concerned Export Promotion Councils/ FIEO/Commodity Boards/ Authorities.

\section{Selection of product}

All items are freely exportable except few items appearing in the prohibited/ restricted list.

After studying the trends of export of different products from India proper selection of the product(s) to be exported may be made.

\section{Selection of Markets}

An overseas market should be selected after research covering market size, competition, quality requirements, payment terms, etc. Exporters can also evaluate the markets based on the export benefits available for few countries under the FTP. Export promotion agencies, Indian Missions abroad, colleagues, friends, and relatives might help gather information.

\section{Finding Buyers}

Participation in trade fairs, buyer-seller meets, exhibitions, $\mathrm{B} 2 \mathrm{~B}$ portals, web browsing is effective tools to find buyers. EPC's, Indian Missions abroad, overseas chambers of commerce can also be helpful. Creating a multilingual Website with a product catalogue, price, payment terms, and other related information would also help. 


\section{Sampling}

Providing customized samples as per the demands of foreign buyers helps in getting export orders. As per FTP 2015-2020, exports of bonafide trade and technical samples of freely exportable items shall be allowed without any limit.

\section{Pricing/Costing}

Product pricing is crucial in getting buyers' attention and promoting sales because of international competition. The price should be worked out taking into consideration all expenses from sampling to realization of export proceeds based on terms of sale i.e. Free on Board (FOB), Cost, Insurance \& Freight (CIF), Cost \& Freight(C\&F), etc. The goal of establishing export costing should be to sell maximum quantity at a competitive price with maximum profit margin. Preparing an export costing sheet for every export product is advisable.

\section{Negotiation with Buyers}

After determining the buyer's interest in the product, prospects, and continuity in business, demand for giving reasonable allowance/discount in price may be considered.

\section{Covering Risks through ECGC}

International trade involves payment risks due to buyer/ Country insolvency. These risks can be covered by an appropriate Policy from Export Credit Guarantee Corporation Ltd (ECGC). Where the buyer is placing an order without making the advance payment or opening a Letter of Credit, it is advisable to procure a credit limit on the foreign buyer from ECGC to protect against the risk of non-payment.

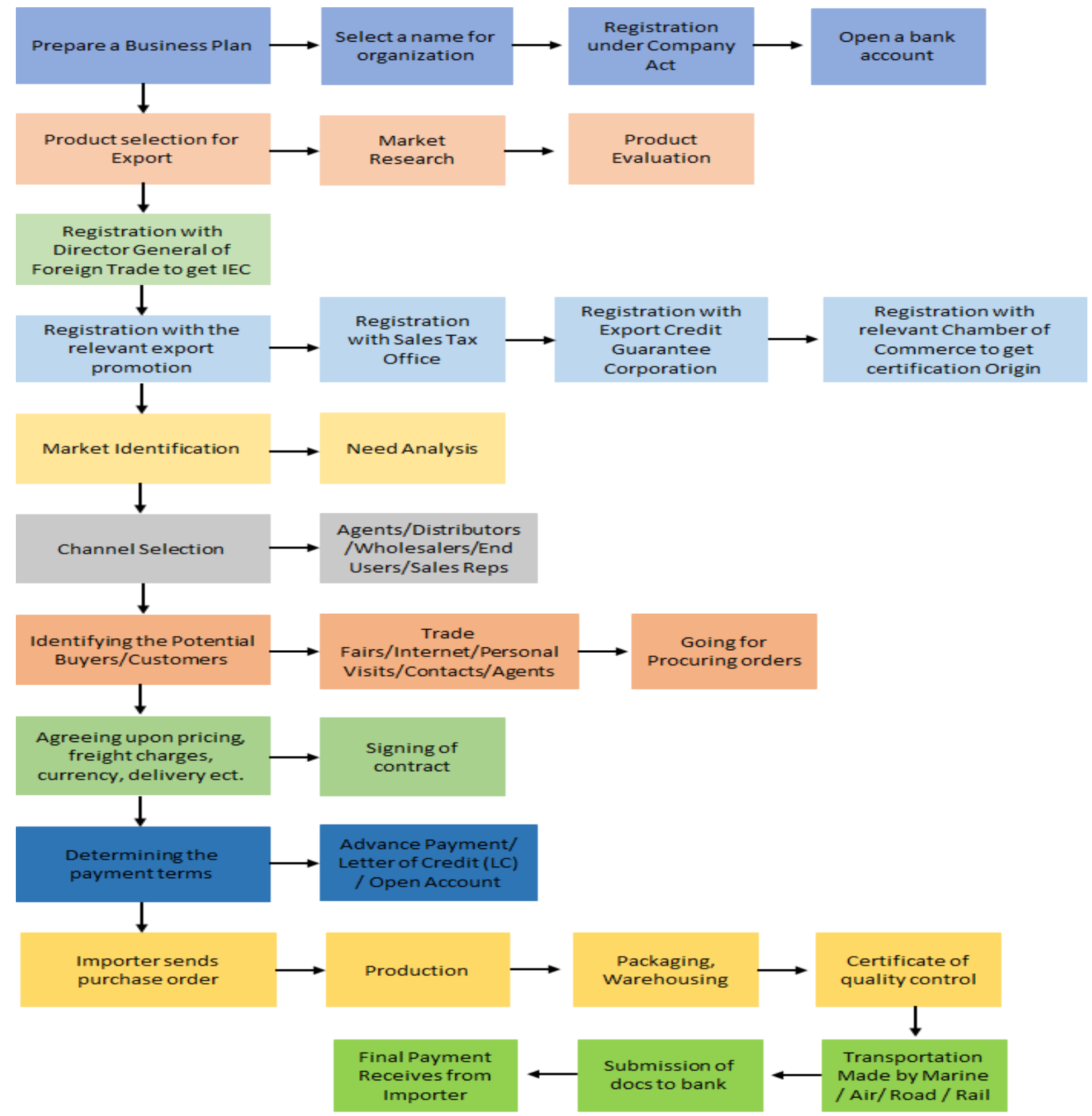

Figure 1: Export Procedure ${ }^{8}$ 


\section{Drug Master File (DMF)}

A Drug Master File (DMF) is a submission to the Food and Drug Administration (FDA) that may be used to provide. Confidential details information about facilities, processes, or articles used in the manufacturing, processing, packaging, and storing of one or more human drugs. ${ }^{9}$

It's important to note that the submission of a DMF is not required by law or FDA but is submitted by a sponsor completely at its discretion.

\section{DMF has divided into 2 parts}

\section{Open part (Applicant's part)}

Contains all the required information related to a method of manufacture and a brief outline of a method of manufacture, potential impurities, manufacturing system, etc.

\section{Closed Part (Restricted part):}

Contains Confidential information on the manufacture of API like Extraction, validation, process, solvents used, reactions, temperature, conditions, critical steps in manufacture, etc. ${ }^{10}$

\section{Apart from this DMF is divided into 5 types}

\section{Type I DMF}

A Type I DMF is recommended for a person outside of the United States to assist FDA in conducting on-site inspections of their manufacturing facilities. The DMF should describe the manufacturing site, equipment capabilities, and operational layout.

It contains information about the plant information like

- Manufacturing site.

- Equipment capabilities.

- Operational layout.

- Corporate headquarters.

- $\quad$ Site Address.

\section{Type II DMF}

Drug Substance, Drug Substance Intermediate, and Material used in their Preparation

Short summary of all significant steps involved in the manufacturing and control of drug intermediate or substance and detailed guidelines on what should be part Type II DMF

- Guideline for Submitting Supporting Documentation in Drug Applications for the Manufacture of Drug Substances.
- Guideline for the Format and Content of the Chemistry, Manufacturing, and Controls Section of an Application.

\section{Drug Product}

Manufacturing procedures and controls for finished dosage forms should be submitted in DMF

- Guideline for the Format and Content of the Chemistry, Manufacturing, and Controls Section of an Application.

- Guideline for Submitting Documentation for the Manufacture of and Controls for Drug Products

- Guideline for Submitting Samples and Analytical Data for Methods Validation

\section{Type III DMF}

It contains detailed information on the packaging material used. i.e.

- Intended use of the packing material.

- Composition of the packing material.

- Name of the suppliers.

- Specifications.

- Toxicological data if any such material available.

Data supporting the acceptability of the packaging material for its intended use should also be submitted as outlined in the "Guideline for Submitting Documentation for Packaging for Human Drugs and Biologics."

\section{Type IV DMF}

It includes information of each additives along with proper identification method, characterizing procedure, and test method and \% composition. Toxicological data should be provided if any such material available.

\section{Type V}

All FDA accepted reference information. FDA discourages the use of Type $V$ DMF's for miscellaneous information, duplicate information, or information that should be included in one of the other types of DMF's. ${ }^{11}$

\section{Common Technical Document (CTD)}

Common Technical Document is an essential document to be submitted to the regulatory body as a supportive list of leaflets attached with the registration applications for pharmaceuticals to get market authorization. Mainly CTD tells about the format for the data. 


\section{DMF Submission and Reviewing Cycle}

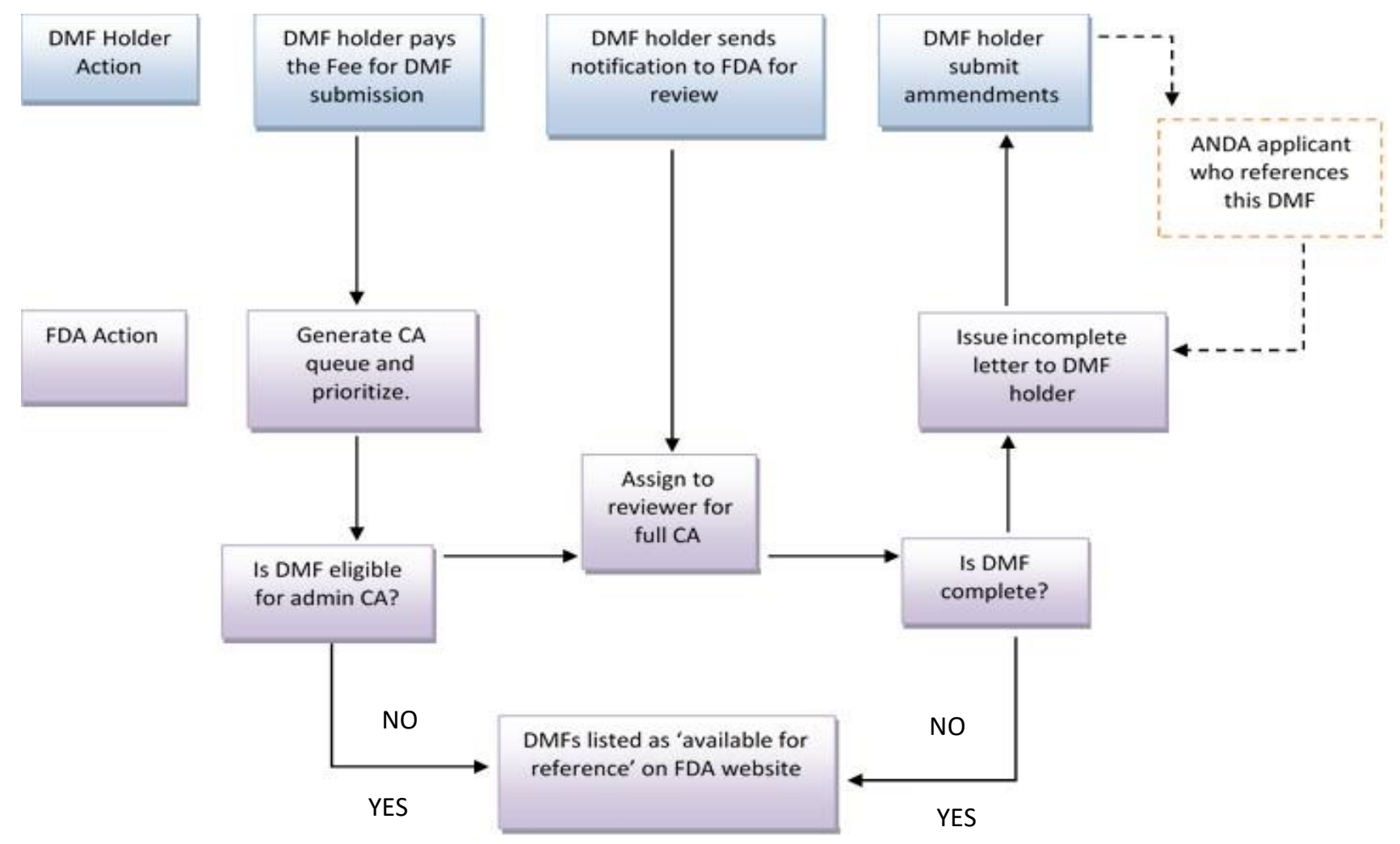

Figure 2: DMF Submission and Reviewing Cycle ${ }^{11}$

\section{CTD Triangle}

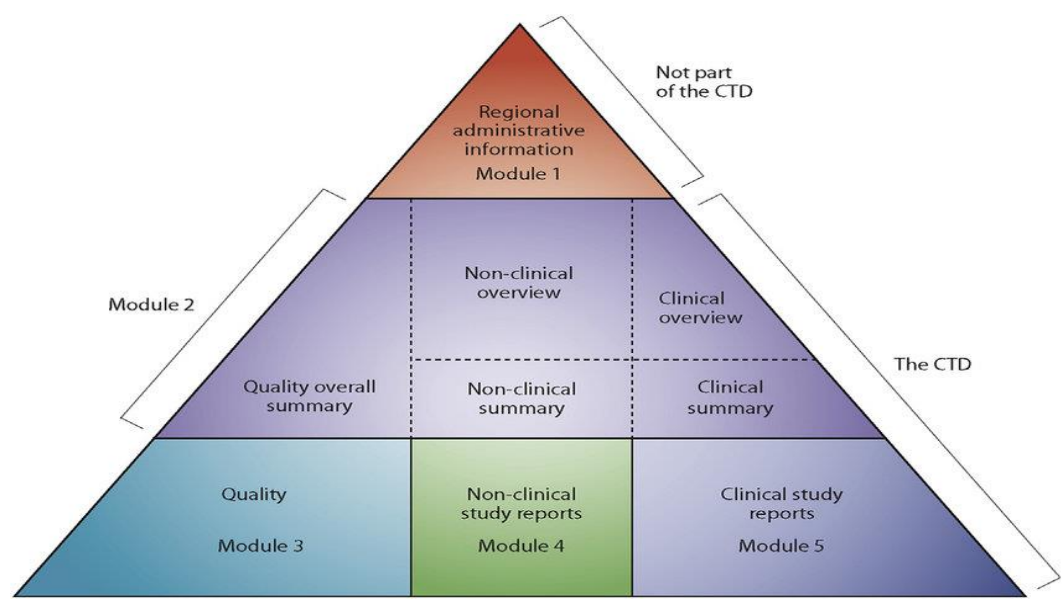

Figure 3: CTD Triangle ${ }^{12}$

Commonly, RA expert knows the documents to be submitted while getting approval for any drug product. But CTD mainly tells about the organization of the information in order. CTD documents should be clear, unambiguous, and transparent. Accordingly, it is having 5 modules.

- Module 1: Administrative and prescribing information

- Module 2: Common Technical Document Summaries (Quality Overall summary)

- Module 3: Quality Data

- Module 4: Non- Clinical study reports

- Module 5: Clinical Study reports

Table 2: Difference between CTD Dossier and DMF ${ }^{12,13}$

\section{CTD Application (Dossier)}

Must be filed by an applicant Comes under the regulatory status

Each application and its supplements are entered into a common database Submitted to intended review division

The review procedure is different than that of DMF

Approval timeline is there

\section{DMF Submission}

Not mandatory to file DMF

No such regulations

DMF's are entered in a separate database as per the type

Submitted to Regulatory body

Reviewed only when referenced with NDA/

ANDA applications

No approval timeline 
- $\quad$ CTD dossier should be detailed and easily acceptable by the regulatory authority.

- $\quad$ The documents should be arranged in such a way that they can be easily reviewed by the reviewer.

- Documents submitted should be signed and dated.

- Labelling should be mentioned as per the country's regulatory guidelines.

- $\quad$ Required documents should be submitted according to the checklist to avoid rejection of the application or queries which in turn speed up the review process and approval.

- The justification for certain tests should be mentioned and supportive documents should be attached.

- Once the dossier is prepared before sending it has to be checked and verified for any mistakes.

- While in the clinical study report (Module 5) CRF, all study reports should be attached.

- $\quad B M R$ is required not MFR.

- Some countries ask for validation certificates that should be up to date.

- Changes done in any batches should be notified and justified.

- Amendments, supplements should be submitted to the regulatory body.

\section{Electronic Common Technical Document (eCTD)}

eCTD is an electronic Common Technical Document, an electronic format where the information and document are submitted to the regulatory body electronically by using the software. Some of the eCTD software is Pharm ready, Edeos, etc. eCTD submission is for applications, amendments, variations, supplements, reports, Master formulae, etc. Understanding the eCTD format and applying successfully in submission is the biggest hurdle. While the sponsor or the applicant may face a problem when the documents do not fit into the format because the application or submission shall be bounced back known as technical rejection. ${ }^{14}$

Software using for eCTD application should be validated.

\section{Requirements of eCTD}

1. Copy and paste.

2. Verifying and printing documents.
3. Document Annotation.

4. Export of information to databases.

\section{Modular Structure of eCTD ${ }^{15}$}

Overall structure of submission is defined by XML eCTD DTD (Document Type Definition). The XML file is the backbone for eCTD submission. The purpose of XML backbone is,

- To manage meta-data of the entire submission like information about submitting and receiving organization, manufacturer, ID, etc., and documents.

- To form a comprehensive table of contents and provide corresponding navigation aids.

\section{Common Formats of eCTD}

1. Narrative: Portable Document Format (PDF) [Calibri 12]

2. Structure: Extensible Mark-up Language (XML) 3. Graphic: Use PDF, whenever PDF is not supporting, use Joint Photographic Experts Group (JPEG), Portable Network Graphics (PNG), Scalable Vector Graphics (SVG), and Graphic Interchange Format (GIF).

3. Font size 9 and 10 are suggested for tables.

\section{Folder and File Naming Conventions}

- The maximum length of the name of a single folder or file is 64 characters.

- The folder name should be written in lower case only. For example: Study Report 1 should be written as study-report-1.

- The file should not exceed more than $2 \mathrm{~GB}$

- Hyperlink- "Insert cross- Reference" feature in MS word is known as Hyperlinking

- Hyperlink improves the overall quality and accuracy of the complete file.

- eCTD will be submitted in Electronic Submission Gateway (ESG)

- All documents should be scanned properly which will help to recognize the file.

- Scanning will be done by using OCR software (Optical Character Recognition). 


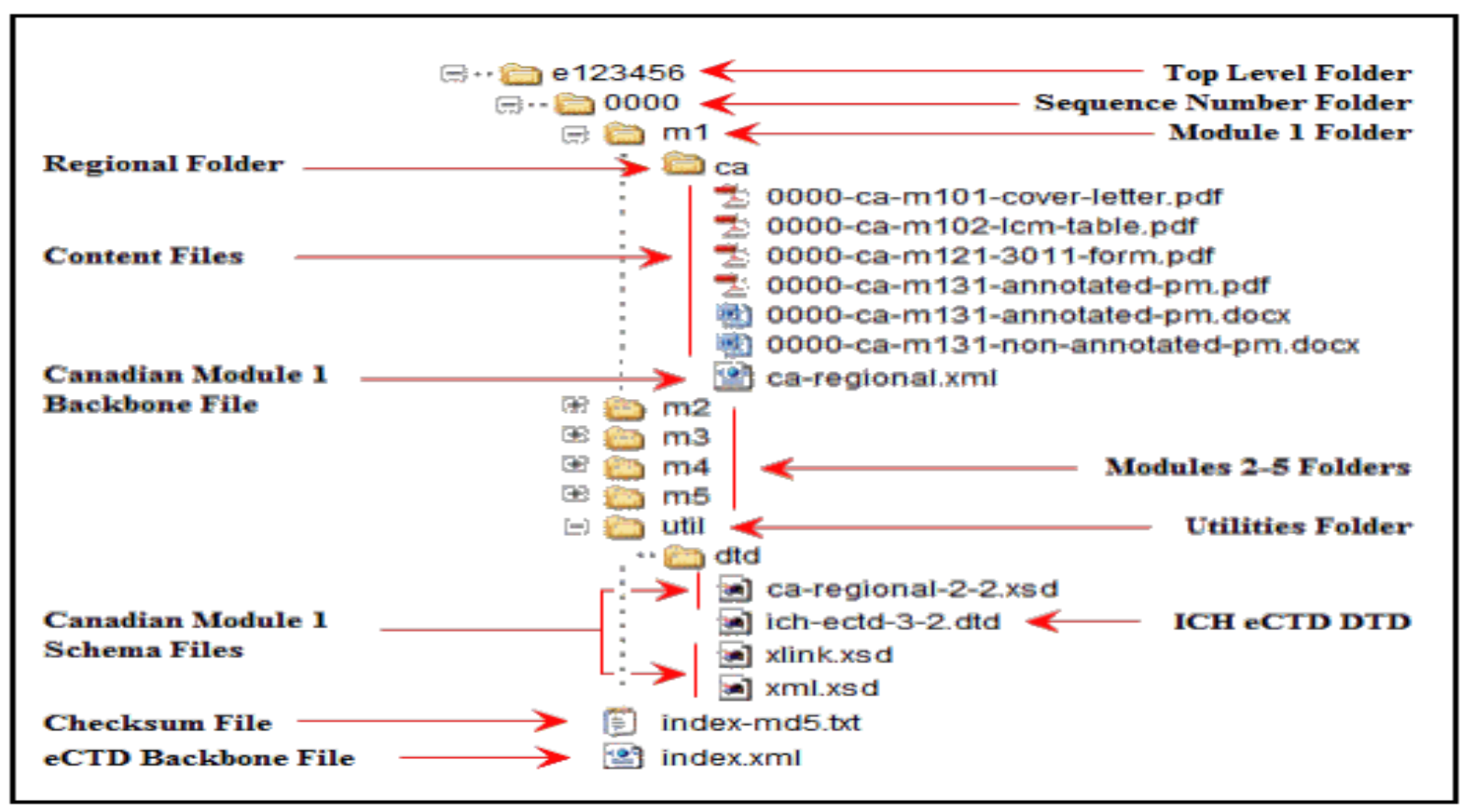

Figure 4: Folder Structure for eCTD Application ${ }^{16}$

\section{Advantages of eCTD}

1. Reduced cost in producing, checking, and storage of paper documents

2. Easy to Review

3. Faster process

4. Greater search functionality

5. Easy to manage the dossier life cycle

6. Can reuse the documents

7. Easy to do any amendments

8. Reviewer is friendly in comparing the dossier with amendments.

9. Several people can read the documents at the same time.

10. More predictable format

11. More convenient for exchange of information.

12. Time-saving process

\section{ASEAN Common Technical Document (ACTD) ${ }^{19}$}

ASEAN Common Technical Document (ACTD) ASEAN (Association of southeast Asian Nations) Common Technical Document (ACTD) is a structured document for the registration of pharmaceuticals in ASEAN countries.

Table 3: ASEAN countries and their regulatory bodies ${ }^{17}$

\begin{tabular}{|c|c|}
\hline Country & Regulatory Body \\
\hline Indonesia & $\begin{array}{c}\text { National Agency of Drug and } \\
\text { Food Control (NADFC) }\end{array}$ \\
\hline Vietnam & $\begin{array}{c}\text { Drug Administration of } \\
\text { Vietnam }\end{array}$ \\
\hline
\end{tabular}

\begin{tabular}{|c|c|}
\hline Thailand & Thai FDA \\
\hline Singapore & Health Science Authority (HAS) \\
\hline Malaysia & $\begin{array}{l}\text { National Pharmaceutical } \\
\text { Regulatory Agency (NPRA) }\end{array}$ \\
\hline Philippines & $\begin{array}{l}\text { Food and Drug Administration } \\
\text { (FDA) }\end{array}$ \\
\hline Brunei & Ministry of Health \\
\hline Cambodia & Department of Drugs and Food \\
\hline Myanmar & $\begin{array}{l}\text { Food and Drug Administration } \\
\text { (FDA) }\end{array}$ \\
\hline Laos & Food and Drug Department \\
\hline
\end{tabular}

\section{ACTD includes 4 parts}

Part 1: Table of Contents, Administrative data, and Product information

Section A: Introduction.

Section B: Overall ASEAN CTD Table of contents

Section C: Documents like registration application, product datasheet, prescribing information, and labelling.

\section{Part 2: Quality Document}

Section A: Table of Contents.

Section B: Quality Overall summary.

Section C: Body of Data.

Part 3: Non- clinical Document

Section A: Table of Contents.

Section B: Non- clinical Overview.

Section C: Non-clinical written and tabulated summaries.

- Pharmacology. 
- Pharmacokinetics.

- Toxicology.

Section D: Non- clinical Study Reports,

- Pharmacology.

- Pharmacokinetics.

- Toxicology.

\section{Part 4: Clinical document}

Section A: Table of Contents

Section B: Clinical Overview

Section C: Clinical Summary

- Summary of Biopharmaceutics and Associated Analytical Methods.

- Summary of Clinical Pharmacology Studies.

- Summary of Clinical Efficacy.

- Summary of Clinical Safety.

- Synopses of Individual Studies.

Section D: Tabular Listing of All Clinical Studies. Section E: Clinical Study Reports.

Section F: List of Key Literature References.

The registration fee will differ from country to country. The documents shall be submitted to the particular regulatory authority. The documents related to drug substances and drug products and a new chemical entities will be according to the country's requirements. ${ }^{18}$

Table 4: Differences between CTD/ eCTD/ ACTD ${ }^{19}$

\begin{tabular}{|c|c|c|}
\hline CTD & eCTD & ACTD \\
\hline $\begin{array}{l}\text { Common } \\
\text { Technical } \\
\text { Document }\end{array}$ & $\begin{array}{l}\text { Electronic } \\
\text { Common } \\
\text { Technical } \\
\text { Document }\end{array}$ & $\begin{array}{c}\text { ASEAN Common } \\
\text { Technical } \\
\text { Document }\end{array}$ \\
\hline Paper submission & $\begin{array}{c}\text { Electronic (Using } \\
\text { Software) }\end{array}$ & $\begin{array}{l}\text { Paper or } \\
\text { Electronic }\end{array}$ \\
\hline $\begin{array}{c}\text { Tedious and } \\
\text { Difficult Review } \\
\text { process }\end{array}$ & $\begin{array}{c}\text { Faster review } \\
\text { process }\end{array}$ & $\begin{array}{l}\text { Depends upon } \\
\text { the country }\end{array}$ \\
\hline $\begin{array}{c}\text { Bulk and Large } \\
\text { documents }\end{array}$ & $\begin{array}{l}\text { XML files storage } \\
\text { will be in GB }\end{array}$ & $\begin{array}{l}\text { Large } \\
\text { documents }\end{array}$ \\
\hline $\begin{array}{l}\text { Includes } 5 \\
\text { modules }\end{array}$ & 5 modules & Includes 4 parts \\
\hline $\begin{array}{l}\text { Cross references } \\
\text { include CTD } \\
\text { section number }\end{array}$ & $\begin{array}{l}\text { Cross references } \\
\text { include hyperlink } \\
\text { and bookmark }\end{array}$ & $\begin{array}{c}\text { Cross references } \\
\text { include CTD } \\
\text { section number }\end{array}$ \\
\hline $\begin{array}{c}\text { CTD navigation } \\
\text { through TOC and } \\
\text { Volumes }\end{array}$ & $\begin{array}{l}\text { eCTD navigation } \\
\text { by XML backbone }\end{array}$ & $\begin{array}{l}\text { CTD navigation } \\
\text { through TOC } \\
\text { and Volumes }\end{array}$ \\
\hline Paper volume- A4 & $\begin{array}{c}\text { Layout shall be A4 } \\
\text { or US letter size }\end{array}$ & $\begin{array}{l}\text { Paper volume- } \\
\text { A4 }\end{array}$ \\
\hline
\end{tabular}

\begin{tabular}{|c|c|c|}
\hline $\begin{array}{l}\text { Submitted in } \\
\text { Binders or boxes }\end{array}$ & $\begin{array}{l}\text { Submitted in } \\
\text { Binders or boxes }\end{array}$ & $\begin{array}{c}\text { Submitted in } \\
\text { Binders or boxes }\end{array}$ \\
\hline $\begin{array}{l}\text { Compiled } \\
\text { electronically with } \\
\text { volumes, tabs, } \\
\text { and slip sheets } \\
\text { and then printed } \\
\text { to paper. }\end{array}$ & $\begin{array}{l}\text { Compiled } \\
\text { electronically with } \\
\text { documents in } \\
\text { folders }\end{array}$ & $\begin{array}{l}\text { Compiled } \\
\text { electronically } \\
\text { with volumes, } \\
\text { tabs, and slip } \\
\text { sheets and then } \\
\text { printed to } \\
\text { paper. }\end{array}$ \\
\hline
\end{tabular}

\section{CONCLUSION}

The registration and approval phase is a very crucial part of commercialization of the pharmaceutical products. As per the regulatory point of view, one has to prepare and compile the documents as per the CTD module. But other requirements like import-export code, Drug master file, and technical documentation are the supportive documents to be submitted to the regulatory body for review and approval. In this article we have covered all the certification process such as COA and COPP also actual processes like DMF filing and reviewing system, arrangements of folders in eCTD structure and differences between the CTD, eCTD, and ACTD module for better understanding in regulatory point of view.

\section{REFERENCES}

1. Export-import bank of India, 2016. Indian Pharmaceutical Industry: Challenges \& Prospects. MUMBAl, Occasional Paper No. 176, Page No. 11.Policy landscape reforms for strengthening Indian Pharmaceutical industry

2. Handoo S, Khera D, Nandi P, Sahu S and Arora V, A comprehensive study on regulatory requirements for development and filing of generic drugs globally, International Journal of Pharmaceutical Investigation, 2012; 2(3): 99.

3. Sengar G, Pharmaceutical Regulatory Agencies and Organizations around the World: Scope and Challenges in Drug Development, 2012. [Article Ref. ID. PharmatutorART-1316]

4. Indian Trade Portal, Pharmaceutical Industry in India. 2021, Available at: $<$ https://www.indiantradeportal.in/vs.jsp?lang=0\&id=0, $30,50,175$.

5. Department of pharmaceuticals, 2020. 2019-20 ANNUAL REPORT. Government of India Ministry of Chemicals \& Fertilizers, pp. Page No. 3-4

6. Indian Trade Portal, How to Export, 2014; Available at: $<$ https://www.indiantradeportal.in/vs.jsp?lang=0\&id=0, $25,44$.

7. Government of India Ministry of Commerce and Industry, Handbook of procedures. New Delhi: Gazettee of india extraordinary (part-1, section-1), 2015; Public Notice No. 01/2015-2020.

8. Shivam K, Export procedure flow chart. 2021; CADMIA. Available $<$ https://www.academia.edu/34526621/Export_procedur e_flow_chart. 
9. U. S. Food and Drug Administration, Guideline for Drug Master Files (DMF), 2015 Available at: $<$ https://www.fda.gov/drugs/drug-master-files$\mathrm{dmfs} /$ guideline-drug-master-files-dmf.

10. Agarwal P and Badjatya J, DMF filing in US, EUROPE and CANADA. International Journal of Drug Regulatory Affairs, 2018; 3(4): 9-17.

11. Shaw B, Drug master files under GDUFA: DMF Basics. In: FDA Small Business Office Webinar, 2013; Available at: $<$ https://www.fda.gov/media/85079/download.

12. $\mathrm{ICH}$, CTD, 2021Available at: $<$ https://www.ich.org/page/ctd.

13. Drug Master File, 2015 Available at: <https://www.slideshare.net/cyclonepharma/dmf-drugmaster-file.

14. Moffett D, eCTD Regulatory Submissions: Hints \& Common Mistakes to Avoid, 2019; Available at: $<$ https://www.nuventra.com/resources/blog/regulatorysubmissions-ectd.

15. U.S. Department of Health and Human Services, 2003. M2 eCTD: electronic common technical document specification. Available at: <https://www.fda.gov/media/71513/download> Food and Drug Administration, pp.2-3.

16. Canada. Guidance Document: Preparation of Drug Regulatory Activities in the Electronic Common Technical Document Format, 2015; Available at: $<$ https://www.canada.ca/en/healthcanada/services/drugs-health-products/drugproducts/applications-submissions/guidancedocuments/ectd/preparation-drug-submissionselectronic-common-technical-document.

17. ASEAN, one vision one identity one community, ASEAN Member States - 2021, Available at: <https://asean.org/asean/asean-member-states/> [Accessed 1 April 2021].

18. The ASEAN Secretariat Jakarta, ASEAN Common Technical Dossier (ACTD), 2016; Available at: <https://asean.org/storage/2017/03/68.-December-2016ACTD.pdf> Jakarta, pp.115-171.

19. Rai K and Rao D, Regulatory requirements for the registration of pharmaceutical products in malaysia. World Journal of Pharmaceutical Research, 2018; 9(4): 842-913.

Source of Support: The author(s) received no financial support for the research, authorship, and/or publication of this article.

Conflict of Interest: The author(s) declared no potential conflicts of interest with respect to the research, authorship, and/or publication of this article.

For any question relates to this article, please reach us at: editor@globalresearchonline.net New manuscripts for publication can be submitted at: submit@globalresearchonline.net and submit_ijpsrr@rediffmail.com 